\title{
Itinerarium liturgiczne po Rzymie
}

Rzym jest znany ze swoich zabytków, które wiążą się z chrześcijaństwem. Jednak na słynne i wielkie bazyliki nie można patrzeć tylko przez pryzmat lat, w jakich powstawały, czy też stylów sztuki występujących w różnych epokach, ale warto spojrzeć i nawiedzać je również jako miejsca związane z genezą konkretnych przejawów liturgicznych.

Niniejsze opracowanie ma dotyczyć przede wszystkim miejsc, które kryją w sobie historię przejawów liturgii, jakie przetrwały do obecnych czasów. Stąd nie będzie tu mowy o elementach liturgii, które nie występują już obecnie. Dla przykładu można podać chociaż niedziele przedpościa. Otóż niedzielę pięćdziesiątnicy (quinquagesima - zapustna) zaczęto celebrować w bazylice św. Piotra (ok. 520) - teksty GeV 84-881, niedzielę sześćdziesiątnicy (sessagesima - mięsozapustna) w bazylice św. Pawła za Murami (po IV synodzie w Orleans - 541) - teksty: GeV 73-77, a niedzielę siedemdziesiątnicy (settuagesima - starozapustna) w bazylice św. Wawrzyńca (przełom VI i VII wieku) - teksty: GeV 69-72 ${ }^{2}$. Te trzy niedziele przed wielkim postem podczas reformy po Soborze Watykańskim II nie weszły już do celebracji roku liturgicznego ${ }^{3}$.

${ }^{1}$ Liber Sacramentorum Romanae Aeclesiae ordinis anni circuli. Cod. Vat. Reg. lat. 316, Paris Bibl. Nat. 7193, 41/56 (Sacramentarium Gelasianum), hrsg. von L. C. Mohlberg in Verbindung mit L. Eizenhöfer, P. Siffrin, Roma 1981 (Rerum Ecclesiasticarum Documenta. Series Maior. Fontes, 4).

${ }^{2}$ A. Adam, L'anno liturgico. Celebrazione del mistero di Cristo, Torino 1984, s. 102; P. Jounel, L'anno, [w:] La Chiesa in preghiera, ed. A. G. Martimort, t. 4: La Liturgia e il tempo, Brescia 1984, s. 90.

${ }^{3}$ Por. A. Bugnini, La reforma liturgica (1948-1975), Roma 1983, s. 304. 
Bazylika S. Maria Maggiore

\section{Śpiew na wejście}

Śpiew na wejście jest już przedstawiony w Liber Pontificalis papieża Celestyna I (422-431)4. Jednak trwa dyskusja, czy chodziło wtedy o śpiew na wejście, ponieważ widziano $w$ tym opisie także śpiew na przygotowanie darów ${ }^{5}$. Św. Augustyn podaje, że w uroczystość Zmartwychwstania Pańskiego, po wejściu do bazyliki biskup pozdrawiał wiernych, następnie siadał, aby wysłuchać czytań. Nie ma tutaj mowy o śpiewie na wejście ${ }^{6}$.

Ordo Romanus I 45-80 (koniec VII wieku) opisuje dokładnie obrzęd wejścia. Papież, który przybywał z Lateranu (w tym przypadku w uroczystość Zmartwychwstania Pańskiego) do S. Maria Maggiore, wchodził do zakrystii, gdzie wkładał na siebie szaty liturgiczne. Schola wcześniej zajmowała miejsce naprzeciw prezbiterium, praktycznie naprzeciw konfesji. Kiedy wszystko było gotowe, subdiakon stojący w drzwiach zakrystii dawał znak papieskim manipularzem, że można zaczynać śpiew na wejście. Obrzęd ten wyglądał następująco: Subdiakon mówił: Scola; ona odpowiadała: Adsum. Subdiakon: Quis psallit? schola odpowiadała: Ille et ille (OR I, 37). Po czym orszak papieski ruszał w stronę prezbiterium, a schola rozpoczynała śpiew na wejście - antiphonam ad introitum (OR I, 44).

Trudno jednak ustalić dokładną datę pojawienia się śpiewu na wejście. Opis występujący w OR I przedstawia sytuacje, które miały miejsce w tzw. kościołach „stacyjnych”. Uroczysta liturgia papieska sprawowana w tych kościołach Rzymu rozwijała się mniej więcej od V wieku

Pojawienie się tzw. Antyfony na wejście (Antiphonam ad introitum) wiąże się z reformą liturgiczną Grzegorza Wielkiego (590-604) Podstawę stanowi cykl psalmodyczny, który papież wprowadził do liturgii pontyfikalnej w 592 roku' .

${ }^{4}$ Le Liber Pontificalis. Texte, introduction et commentaire, ed. L. Duchesne, t. 1, Paris 1981, nr XLV, s. 231

${ }^{5}$ Por. A. Nocent, Storia della celebrazione dell' eucaristia, [w:] Eucaristia. Teologia e storia della celebrazione, Casale Monferrato 1983, s. 199 (Anàmnesis. Introduzione Storico-Teologica alla Liturgia, 3.2).

${ }^{6}$ Por. Augustyn, Państwo Boże, XXII, 8, t. 3, Poznań 1937, s. 592.

${ }^{7}$ M. Andrien, Les Ordines Romani du haut Moyen Age, t. 2:Les textes (Ordines I-XIII), Louvain 1971.

${ }^{8}$ Por. B. Mokrzycki, Droga chrześcijańskiego wtajemniczenia, Warszawa 1983, s. 515, przyp. 207.

${ }^{9}$ Por. A. Reginek, Śpiewy mszalne, [w:] Mysterium Christi,t. 3:Msza święta, red. W Świerzawski, Kraków 1993, s. 199. 


\section{Pasterka}

Za czasów pontyfikatu Sykstusa III (432-440) nastąpiła przebudowa bazyliki Liberiusza, aby w ten sposób uczcić nowo ogłoszony dogmat o macierzyństwie Maryi (Efez 431) i poświęcić tę świątynię Matce Bożej. Papież, dla unaocznienia macierzyństwa Maryi, postanowił w krypcie (pod prezbiterium) odtworzyć stajenkę betlejemską. Pomogli mu w tym przedsięwzięciu pielgrzymi powracający z Ziemi Świętej. Przywieźli oni kawałki skał z Betlejem, które posłużyły do wybudowania Groty Betlejemskiej. Relikwie szopki (cunabulum Domini - kolebka Pana) pojawiły się w Rzymie później ${ }^{10}$. Papież Sykstus III w kaplicy Groty Betlejemskiej w uroczystość Narodzenia Pańskiego celebrował mszę świętą o północy. Była ona przeznaczona dla mieszkańców miasta, ponieważ bramy Rzymu były zamknięte ${ }^{11}$. Tak więc w IV wieku powstaje tradycja tzw. pasterki. Teksty tej mszy świętej zostały później zawarte w $\mathrm{GrH}^{12}$ 36-40/VIII Kalendas Januaris id est XXV die mensie decembris Natale Domini ad Sanctam Mariam Maiorem.

\section{Procesja 2 lutego}

PapieżSergiuszI (687-701) wprowadza w Rzymie procesję przed mszą świętą 2 lutego. Procesja 2 lutego zastąpiła starożytną procesję pogańską, która miała charakter ekspiacyjny i była organizowana co pięć lat na początku lutego. Papież wychodził wtedy z kościoła św. Hadriana ${ }^{13}$ i podążał do bazyliki S. Maria Maggiore wraz z diakonami. Zakładał szaty liturgiczne koloru czarnego. Procesja 2 lutego miała miejsce o świcie. Wierni nieśli w rękach świece, nawiązując do Symeona, który wskazał na Jezusajako „Światło na oświecenie pogan” (Łk2,32). Procesjata miała charakter pokutny. Taką samą procesjęodbywał cesarzw Konstantynopolu, gdzie szedł boso. W IX wieku zwyczaj procesji rozprzestrzenia się też na inne kraje. Charakter pokutny tej procesji wymagał szat fioletowych; tak było aż do 1970 roku $^{14}$. Po Soborze Watykańskim II szaty są koloru białego.

${ }^{10}$ Por. A. Wodnik, Wędrówki po Rzymie. Pierwsze bazyliki chrześcijańskie, Rzym 1987, s. 18n.

${ }^{11}$ Por. A. Nocent, Il tempo della manifestazione, [w:] L'anno liturgico. Storia, teologia e celebrazione, Genova 1988, s. 183 (Anàmnesis. Introduzione Storico-Teologica alla Liturgia, 6).

${ }^{12}$ Le Sacramentaire Grégorien. Ses principales formes d'après les plus anciens manuscrits, t. 1-3, Fribourg 1988-1992.

${ }^{13} \mathrm{Z}$ kurii na Forum Romanum, gdzie mieściła się antyczna siedziba senatu rzymskiego, w 638 roku utworzono kościół św. Hadriana. Natomiast w 1937 roku zlikwidowano kościół, przywracając kurii jej pierwotny wygląd.

${ }^{14}$ Por. A. Adam, L'anno liturgico..., dz. cyt., s. 158; A. Nocent, Il tempo della manifestazione..., dz. cyt., s. 204. 


\section{Kościół św. Anastazji - Narodzenie Pańskie: msza o świcie}

Od końca IV wieku istniału stóp Palatynu kościół określony mianem titulus Anastasiae. Kościół ten, jako budowla, był własnością pobożnej kobiety o imieniu Anastazja ${ }^{15}$ lub, jak twierdzą inni, był on poświęcony Zmartwychwstaniu i zbudowany na wzór bazyliki Anastasis w Jerozolimie. Pod koniec V wieku w tym kościele rozwija się kult św. Anastazji, męczennicy, która była bardzo czczona w Konstantynopolu, a jej obchód przypadał właśnie na 25 grudnia. Stąd kościół na Palatynie otrzymuje tytuł św. Anastazji ${ }^{16}$.

W połowie VI wieku w uroczystość Narodzenia Pańskiego papież celebrował drugą mszę świętą w kościele św. Anastazji, aby w ten sposób uszanować i okazać łączność z wiernymi obrządku wschodniego ${ }^{17}$. Teksty na tę mszę świętą znajdują się w Sakrametarzu Gregoriańskim (GrH 41-48) i są opatrzone tytułem: De nocte ad sanctam Anastasiam. Ciekawostką tego formularza jest stosowanie podwójnych oracji. Pierwsze z nich odnoszą się do Narodzenia Pańskiego, a drugie wspominają św. Anastazję.

W ten sposób aż do dnia dzisiejszego istnieje formularz mszy o świcie w uroczystość Narodzenia Pańskiego.

\section{Bazylika św. Piotra}

\section{Narodzenie Pańskie: msza w dzień}

Narodzenie Pańskie pojawia się w Rzymie w 336 roku. W połowie V wieku oficjum połączone z celebracją mszy świętej miało miejsce w bazylice św. Piotra. Daje o tym świadectwo św. Ambroży, który opisuje papieża Liberiusza (352-366) celebrującego mszę świętą w dzień Narodzenia Pańskiego w bazylice św.Piotra ${ }^{18}$.

${ }^{15}$ Anastazja była prawdopodobnie krewną cesarza Konstantyna Wielkiego - por. H. Fros, F. Sowa, Twoje imię. Przewodnik onomastyczno-hagiograficzny, Kraków 1982, s. 94.

${ }^{16}$ Św. Anastazja poniosła śmierć w starożytnym Sirmium nad Saną (dzisiejsza Sremska Mitrovica w Serbii) prawdopodobnie w czasie prześladowań Dioklecjana w 304 roku. Około 465 roku patriarcha Genadiusz przeniósł jej relikwie do Konstantynopola - por. tamże, s. 93n. Imię św. Anastazji występuje w Kanonie rzymskim. Jest ona patronką cenzury i tkaczy oraz orędowniczką w czasie bólu głowy.Jej atrybutami są nożyce w ręku (narzędzie pracy cenzora) oraz postronki, którymi przywiązywano ją do czterech pali, a także stos, na którym ją spalono - por. U. Janicka-Krzywda, Atrybut, patron, symbol, czyli co o świętych i błogosławionych powinien wiedzieć przewodnik, Kraków 1988, s. 26.

${ }^{17}$ Por. A. Nocent, Il tempo della manifestazione..., dz. cyt., s. 184.

${ }^{18}$ Por. Ambroży, Virginibus ad Marcellinam sororem suam, 3, 1, [w:] Sancti Ambrosii, Mediolanensis episcopi, opera omnia, accurante et denuo recognoscente J.-P. Migne, t. 2, cz. 1, Parisiis 1880, 
Stąd w czasach kiedy ustaliły się już trzy msze święte w uroczystość Narodzenia Pańskiego (VI wiek), celebracja według tzw. formularza w ciągu dnia odbywała się w bazylice św. Piotra ${ }^{19}$. Wskazują na to wprost teksty zawarte w Sakramentarzu Gregoriańskim, a zatytułowane: In Natale Domini ad sanctam Petrum (GrH 49-53). Ta msza święta była przeznaczona dla ludności spoza Rzymu, ponieważ w tamtych czasach wzgórze Watykańskie nie należało do miasta. Tak więc z bazyliką św. Piotra jest związana tradycja trzeciej mszy świętej w uroczystość Narodzenia Pańskiego, tzw. mszy w dzień.

\section{Święto Podwyższenia Krzyża}

Z bazyliką św. Piotra wiąże się również pojawienie się znanego już wcześniej w Jerozolimie i Konstantynopolu (V wiek) święta Podwyższenia Krzyża (Exaltatione Sanctae Crucis). W VI wieku do Rzymu zostały sprowadzone relikwie Krzyża Świętego. Właśnie w bazylice watykańskiej papież unosił (exaltatio) relikwie krzyża, aby wierni mogli je adorować. Papież Sergiusz I (687-701) przenosi relikwie na Lateran, do kościoła Świętego Krzyża Jerozolimskiego.

\section{Bazylika św. Jana na Lateranie - hymn Chwała na wysokości}

Hymn Chwała na wysokości występuje już w Konstytucjach apostolskich ${ }^{20}$ i znany jest w różnych obrządkach liturgicznych. Papież Stefan III (768-772) wydał specjalny przywilej biskupom podmiejskim, którzy na przemian (co tydzień inny) celebrowali w bazylice św. Jana na Lateranie ${ }^{21}$ przy ołtarzu św. Piotra, aby mogli śpiewać Gloria in excelsis podczas mszy świętych niedzielnych i świątecznych (Hic statuit ut omni dominico die a septem episcopis cardinalibus ebdomadariis, qui in ecclesia Salvatoris observant, missarum solemnia super altare

k. 219 (Patrologiae Cursus Completus. Series Latina, 16).

${ }^{19}$ Por. A. Nocent, Il tempo della manifestazione..., dz. cyt., s. 183.

${ }^{20}$ Konstytucje apostolskie, VII, 47, [w:] Konstytucje apostolskie oraz Kanony Pamfilosa z apostolskiego synodu w Antiochii. Prawo kanoniczne świętych Apostołów. Kary świętych Apostołów dla upadłych. Euchologion Serapiona, przekł. S. Kalinkowski, A. Caba, układ i oprac. A. Baron, H. Pietras, Kraków 2007, s. 213 (Synodi et Collectiones Legum, 2; Źródła Myśli Teologicznej, 42).

${ }^{21}$ Określenie Lateran pochodzi od nazwiska rodziny Lateranów, do której należała druga żona cesarza Konstantyna, budowniczego bazyliki w IV wieku. Początkowo bazylika była poświęcona Zbawicielowi, a za pontyfikatu Grzegorza Wielkiego (590-604) występuje pod wezwaniem dwóch świętych Janów: Chrzciciela i Ewangelisty. Obecnie nazywa się ją potocznie Jana na Lateranie - por. A. Wodnik, Pierwsze bazyliki chrześcijańskie, Rzym 1987, s. 11-13. 
beati Petri celebraretur et Gloria in excelsis Deo ediceretur) ${ }^{22}$. Stąd również w Ordo Missae Sakramentarza Gregoriańskiego znajduje się rubryka: Item dicitur gloria in excelsis deo, si episcopus fuerit, tantummodo die dominico, sive diebus festis; a praesbyteris autem minime dicitur nisi solo in pascha ( $\mathrm{GrH} 2$ ).

\section{Katakumby św. Sebastiana - uroczystość Świętych Apostołów Piotra i Pawła}

Wspólna uroczystość Świętych Apostołów Piotra i Pawła celebrowana 29 czerwca znana jest w Rzymie w połowie III wieku. Przypuszcza się, że wspólny obchód był podyktowany tym samym dniem śmierci męczeńskiej. Wydaje się jednak, że należy wziąć pod uwagę dzień przeniesienia relikwii. Wiadomą jest rzeczą, że św. Piotr został pochowany na Watykanie ${ }^{23}$, a św. Paweł przy Via Ostiense. Jednak w czasie prześladowań za panowania cesarza Waleriana (253260) został wydany dekret (258), który zabraniał uprawiać kult na cmentarzach. Stąd chrześcijanie w obawie przed zbezczeszczeniem grobów obu Apostołów przenieśli ich relikwie do katakumb św. Sebastiana (Via Appia) dnia 29 czerwca 258 roku. Wydaje się zatem, że dzień przeniesienia relikwii do katakumb wpłynął na datę wspólnego obchodu Świętych Apostołów Piotra i Pawła ${ }^{24}$.

Po Edykcie mediolańskim (313) przystąpiono do budowy bazylik: jednej na Watykanie, a drugiej za murami wiecznego miasta.

Ten wspólny obchód jest widoczny w późniejszych tekstach liturgicznych: Ve ${ }^{25}$ 280-282 (In Natale Apostolorum Petri et Pauli), GeV 915-930. W tym drugim sakramentarzu są aż cztery formularze: In vigilia Apostolorum Petri et Pauli. III Kalendas iulias (GeV 915-917, In Natale Sancti Petri propriae. III Kalendas iulias (GeV 918-920), In Natale Apostolorum Petriet Pauli. III Kalendas iulias (GeV 921-926) oraz In Natale Sancti Pauli propriae. III Kalendas iulias (GeV 927-930). Natomiast Sakramentarz Gregoriański podaje 29 czerwca jako dzień poświęcony tylko św. Piotrowi: III Kalendas iulias id est XXVIIII die mensis iulii. Natale

${ }^{22}$ Le Liber Pontificalis..., t. 1, nr XCVI, s. 478; por. Antiqui libri rituals Sanctae Romanae Ecclesiae, [w:] Sancti Gregorii Papae I, cognomento Magni, opera omnia, accurante J.-P. Migne, t. 4, Lutetiae Parisiorum 1849, k. 865c (Patrologiae Cursus Completus. Series Latina, 78).

${ }^{23}$ Etruskowie będący w Rzymie do 509 roku przed Chrystusem mieli na obecnym wzgórzu świątynię ku czci boga Vaticanusa, który otwierał noworodkom usta do pierwszego krzyku. Stąd dzisiejsza nazwa Watykan - por. A. Wodnik, WędrówkipoRzymie. Śladamiśw. Piotra, Rzym 1986, s. 4.

${ }^{24}$ Por. A. Adam, L'anno liturgico..., dz. cyt., s. 244.

${ }^{25}$ Sacramentarium Veronense (Cod. Bibl. Capit. Veron. LXXXV), ed. L. Eizenhöfer, P. Sifrin, L. C. Mohlberg, Roma 1978 (Rerum Ecclesiasticarum Documenta. Series Maior. Fontes, 1). 
Sancti Petri (GrH 594-603). 30 czerwca jest: Pridie Kalendas iulias id est XXX die mensis iulii. Natale Sancti Pauli (GrH 604-606). Jednak 28 czerwca była wigilia poświęcona tylko św. Piotrowi: III Kalendas iulias id est XXVIII die mensis iulii. Vigilia Sancti Petri. Oratio ad missas (GrH 589-593).

\section{Panteon - uroczystość Wszystkich Świętych}

W Panteonie ${ }^{26}$ można upatrywać początków uroczystości Wszystkich Świętych w Kościele Zachodnim. Należy jednak nadmienić, że pierwsze ślady tego obchodu pojawiły sięjuż w Antiochii, a data była związana z pierwszą niedzielą po Zesłaniu Ducha Świętego. Świadectwem tego może być homilia wygłoszona na tę okoliczność przezśw. Jana Chryzostoma - Złotoustego (350-407). Wspomina w niej święto wszystkich Męczenników ${ }^{27}$. Termin ten pozostał na długo w Kościele Wschodnim. Niemniej jednak na tamtejszych terenach były znane dwie inne daty dotyczące tej samej celebracji. Otóż Efrem Syryjczyk wspomina 13 maja, a w liturgii wschodnio-syryjskiej data ta jest związana z piątkiem po Wielkanocy, również jako święto wszystkich Męczenników ${ }^{28}$.

W Rzymie została nawiązana tradycja do Kościoła Wschodniego. Cesarz Fokas przekazał zamkniętą od ponad 100 lat i nieużywaną świątynię pogańską (Panteon) papieżowi Bonifacemu IV (608-615), który kazał ją odnowić. Dnia 13 maja 609 (lub 610) roku poświęcił ją ku czci Najświętszej Dziewicy Maryi oraz wszystkich Męczenników, ale przedtem jednak polecił przywieźć 28 wozów relikwii świętych z katakumb do kościoła. Zatem rzymskie początki uroczystości Wszystkich Świętych wiążą się z tym kościołem (Panteonem), aczkolwiek wspominano wówczas samych tylko Męczenników. W ten sposób święto 13 maja dało początek obecnej uroczystości Wszystkich Świętych.

Obecna data 1 listopada wiąże się z papieżem Grzegorzem III (731-741), który poświęcił w bazyliceśw. Piotra oratorium „ku czci Zbawicielai Jego Świętej Matki,

${ }^{26}$ Panteon powstał w latach 27-25 przed Chrystusem za czasów Marka Agryppy, syna Lucjusza. W latach 120-125 Panteon został gruntownie przebudowany podczas panowania cesarza Hadriana. Ciekawostką tej budowli jest fakt, iż średnica Panteonu (43,3 m) stanowi równocześnie jego wysokość. Ponadto budowla nie posiada okien, a jedyne światło naturalne wpadające do wnętrza przechodzi przez otwór (o średnicy $9 \mathrm{~m}$ ) w kopule - por. A. Broż, Rzym i Watykan, Rzym 1982, s. 93-94.

${ }^{27}$ Por. Jan Chryzostom, Laudatio ss. Omnium qui martyrium toto terrarum orbe sunt passi, [w:] S. P. N. Joannis Chrysostomi, archiepiscopi Constantinopolitani, opera omnia quae exstant, accurante et denuo recognoscente J.-P. Migne, t. 2, Lutetiae Parisiorum 1862, k. 705-706 (Patrologiae Cursus Completus. Series Greaca, 50).

${ }^{28}$ Por. M. Kunzler, Liturgia Kościoła, Poznań 1999, s. 713. 
wszystkich Apostołów, Męczenników i wszystkich Sprawiedliwych, którzy posnęli na całym kręgu ziemi" ${ }^{29}$. Data 1 listopada wywodzi się z połowy VIII wieku i utrwaliła się w Anglii i Irlandii. Papież Grzegorz IV (827-844) nakłonił Ludwika Pobożnego do wprowadzenia tego święta w całym jego cesarstwie. „Beleth uważa, że święto to przeniesiono z maja na jesień, gdyż dający się na początku roku odczuwać dosyć mocno brak żywności utrudniał przyjmowanie wielkiej liczby pielgrzymów, którzy zdążali do Rzymu na święto 13 maja"30. Mimo to termin majowy przetrwał w Rzymie aż do pontyfikatu Grzegorza VII (1073-1085) ${ }^{31}$.

Powyższe opracowanie pozwala spojrzeć na różne miejsca wiecznego miasta poprzez pryzmat historii liturgii. Zapoznając się z miejscami, gdzie pojawiały się poszczególne przejawy liturgii, ich uwarunkowania historyczne oraz tradycje, łatwiej jest przyswajać sobie nie tylko znajomość Rzymu, ale także obrzędy i święta występujące w dzisiejszym Kościele. Wydaje się, że dzięki takiemu spojrzeniu na Rzym, można by poprowadzić w tym mieście kurs z historii liturgii. Warszawa

ANNA PLESKACZEWSKA

\section{Słowa kluczowe}

Pierwsze tysiąclecie chrześcijaństwa, Rzym, kościół, święto, obrzęd

\section{Summary}

\section{Liturgical itinerary through Rome}

The article indicates places connected with appearance of the particular elements of the modern liturgy. It does not treat elements which existed earlier and do not exist at the present time. And so in St. Mary's Major basilica appear: entrance song, Midnight Mass at Christmas, and procession on February 2; in St. Anastasia's church the morning Mass at Christmas; in St. Peter's basilica Mass on Christmas day and celebration of the feast of Exultation of the Cross in the West; in Lateran basilica appears Glory; St. Sebastian's catacombs explain common celebration of St. Peter's and St. Paul's on June 29 and Pantheon initiates solemnity of All Saints.

\section{Keywords}

The first millennium of the Church, Rome, church, feast, celebration

\footnotetext{
${ }^{29}$ Tamże, s. 714.

${ }^{30}$ Tamże.

${ }^{31}$ Por. H. Fros, Wprowadzenie do Mszy o Świętych, t. 2, Warszawa 1982, s. 392.
} 